\title{
KAWISTARA
}

\section{PARADOKSALITAS DI BALIK KEMEGAHAN BOROBUDUR}

\author{
Bambang Suharto \\ Universitas Negeri Gorontalo \\ Email: unikbali@hotmail.com
}

\begin{abstract}
This article aimes at exploring the destination organization management of Borobudur temple. The approach method used in this writing is descriptive interpretative of organization behavior. The data was collected from literature study, participated observation, and the discussions in the seminars. The research's findings show that the success of organizations managing Borobudur has been focused on the fulfillment of legal and economic responsibilities rather than social ones, as mandated by the Ministry of State-Owned Enterprises in law Nomor 40 of 2007 and Law Nomor 10 of 2009. Moreover, it is aggravated by the behavior of urban society, members of which all have their own interets. Finally, the local community will become more marginalized if the government does not take any serious actions taken to empower them immediately.
\end{abstract}

Keywords: Management, Organization, Destination, Welfare

ABSTRAK

Penulisan artikel ini bertujuan untuk mengetahui tata kelola organisasi destinasi candi Borobudur. Pendekatan metode yang digunakan dalam penulisan, yaitu deskriptif interpretatif mengenai perilaku organisasi yang datanya didapat dari studi literatur, pengamatan terlibat, dan diskusi-diskusi dalam seminar. Hasil temuan menunjukkan bahwa kesuksesan organisasi mengelola candi Borobudur, tidak sebanding dengan tingkat kesejahteraan masyarakatnya karena perilaku organisasi Taman Wisata Candi Borobudur lebih fokus menjalankan tanggung jawab hukum dan ekonomi dari pada tanggung jawab sosial yang diamanahkan oleh visi Kementrian Badan Usaha Milik Negara, Undang-Undang Nomer 40 Tahun 2007, dan Undang-Undang Nomer 10 Tahun 2009. Hal ini juga diperburuk oleh perilaku masyarakat urban yang juga mempunyai kepentingan. Masyarakat lokal akan terus semakin termarginalkan apabila tidak segera dilakukan langkah-langkah pemberdayaan secara serius.

Kata Kunci: Tata Kelola, Organisasi, Destinasi, Kesejahteraan

\section{PENGANTAR}

Belakangan ini penelitian tentang destinasi telah banyak dikaji dalam hal basis teknologi informasi (Bhairawa, Mulatsih, dan Rahayu, 2009; Chen dan Sheldon, 1997), pemasaran (Buhalis, 2000; Fodor dan Werthner, 2005), maupun tata kelola daerah tujuan wisatanya (Getz, Anderson, dan Sheehan, 1998; McElroy, 2003).
Namun, penelitian tentang daerah tujuan wisata, khususnya mengenai pengelolaan organisasinya jarang ditemukan, padahal organisasi ini mempunyai peran sentral yang tidak kalah pentingnya dengan destinasi (Presenza, Sheehan, dan Ritchie, 2005). Mereka menyatakan bahwa seringkali 
kesuksesan sebuah destinasi bergantung kepadanya. Organisasilah yang menjadi aktor penentu pengembangan atraksi, akses, dan amenitas.

Memang tidak dapat dipungkiri bahwa organisasi pengelola daerah tujuan wisata mampu membuat destinasi bermanfaat secara optimal dan berkelanjutan. Organisasi inilah yang pertama-tama akan mewadahi, menggerakkan, dan memerankan pemangku kepentingan dalam mengelola berbagai permasalahan sebuah destinasi. Keberadaan organisasi ini dapat mengakselerasikan kebijakan daerah tujuan wisata dengan memperhatikan kebijakan yang lain secara terarah dan terkoordinasi, seperti undangundang, peraturan, renstra, dan programprogram pariwisata yang lain. Organisasi juga dapat mengintegrasikan rencana pembangunan dan pemasaran daerah tujuan wisata dari pemerintah pusat, provinsi, dan kabupaten/ kota dalam mewujudkan tujuan pariwisata secara terpadu dan berkelanjutan (Budpar, 2010). Barangkali karena alasan itu pulalah organisasi pengelola sebuah destinasi ini penting, bahkan diperebutkan oleh stakeholder-nya, ingin dilibatkan dan diperankan sebagai pengelola destinasi tersebut.

Kompleksitas organisasi pengelolaan destinasi ini melibatkan pihak-pihak yang berkepentingan untuk mendapatkan prioritas yang diuntungkan. Mereka membentuk kelompok-kelompok untuk memperkuat kepentingannya. Kepentingan kelompok yang beragam dengan karakteristik produk dan pemahaman yang bermacam-macam sering menimbulkan konflik. Konflik ini kian hari tampak semakin memanas dan tak kunjung datang penyelesaiannya.

Akar pemicu konflik ialah dugaan akan kurang terintegrasinya pengelolaan organisasi destinasi dalam suatu sistem yang mampu mengoptimalkan kepentingan bersama. Kesenjangan kepentingan muncul ketika optimalisasi pengembangan Candi
Borobudur membuat gaya hidup masyarakat semakin konsumtif dan termarginalkan tanpa diimbangi dengan pemberdayaan mereka. Hal ini ditunjukkan oleh banyaknya penghargaan yang diraih oleh TWC (Taman Wisata Candi) Borobudur, namun, data persentase angka kemiskinan di Kecamatan Borobudur tercatat sebesar $61,7 \%$, peringkat 17 kategori masyarakat miskin dari 22 kecamatan yang ada di Kabupaten Magelang, Jawa Tengah (Kurniawati, 2008).

Masyarakat yang merasa tergusur dan terampas kesejahteraannya melakukan perlawanan menuntut ketidakadilan. Ancaman muncul berkali-kali, antara lain warga masyarakat akan melakukan aksi tutup jalan menuju pintu Candi Borobudur (Aji dalam kapanlagi.com, 2006). Desas-desus revolusi Borobudur pun mulai didengungkan dengan keras dan mulai menghimpun basis kekuatan (suara audien dalam focus group discussion dan sarasehan, 2011). Gejolak kepentingan individu dan kelompok tertentu yang sudah diwadahi dalam organisasiorganisasi nonpemerintah semakin berani menyuarakan perihal ketidakadilan. $\mathrm{Hal}$ ini dikuatirkan akan memuncak dan berakhir pada tindakan anarkis, khususnya terhadap organisasi pengelola destinasi TWC Borobudur. Pengelola Candi Borobudur diduga kurang merespons kepentingan masyarakat setempat. Kalaupun pada akhirnya tindakan anarkis terjadi, semua akan rugi dan citra pariwisata lagi-lagi tercoreng. Oleh karena itu, penting adanya tata kelola organisasi daerah tujuan wisata yang biasanya dikenal dengan istilah MDO (Management of Destination-Organization).

Presenza, Sheehan, dan Ritchie (2005) merupakan peneliti pertama yang mengkaji model DMO (Destination-Management Organization) dari sudut pandang EDM (External-Destination Marketing) dan IDD (Internal- Destination Development). Mereka menggali berbagai pandangannya, yaitu pendekatan IDD dari produk pada sisi 
penawaran dan pendekatan EDM dari pemasaran pada sisi permintaan. Peneliti DMO yang lain adalah Ritchie dan Crouch (2007) dengan latar perencanaan pengelolaan daerah tujuan wisata yang dikenal dengan model DMP (Destination-Management Planning). Crouch lebih menitikberatkan kajiannya pada pemasaran dan tata kelola alam untuk menciptakan pariwisata yang berkelanjutan dan daerah tujuan wisata yang mempunyai daya saing. Pendekatan DMP didasarkan pada dua pilar penyangganya, yaitu destination marketing dan destination management. Namun demikian, perhatian kedua penelitian itu terpusat pada unsur objek dan bukan subjek kepariwisataan sehingga kurang mampu menafsir lebih luas penentu keadaan dalam konflik Borobudur ini. Sehubungan dengan hal itu, penulis lebih akrab menggunakan istilah MDO. MDO lebih cenderung melihat permasalahan ada pada organisasinya. Dengan demikian, perlu penyelesaian agar organisasi sebagai subjek dapat bekerja dengan baik bersama stakeholder-nya dalam mencapai tujuan. Bisa jadi, permasalahan ada pada sisi internal atau sisi eksternal. Hal ini berbeda dengan DMO, seperti dikemukakan oleh kedua peneliti sebelumnya yang cenderung menekankan permasalahan pada destinasi.

Ancangan analisis MDO ini dipilih karena dapat mengungkapkan pengelolaan organisasi dikaitkan dengan kemajuan suatu destinasi di Borobudur dan kesejahteraan masyarakatnya (Bhairawa, Mulatsih, dan Rahayu, 2009). Selanjutnya, keterkaitan unsur-unsur tersebut membentuk nilai (Pitana, 2002) dan secara empiris teruji dapat menyejahterakan masyarakat sekitarnya (Semercioz, Donmez, dan Dursun, 2008; Damanik, 2010).

Lebih khusus, penelitian ini bertujuan untuk mengetahui tata kelola organisasi daerah tujuan wisata Candi Borobudur. Pengorganisasian destinasi yang baik merupakan jaminan kesuksesan suatu pengelolaan destinasi (Greech, 1995:517). Kesuksesan pengelolaan destinasi dapat memberikan manfaat yang sebesar-besarnya kepada pihak-pihak yang berkepentingan secara adil dan merata, termasuk kesejahteraan masyarakat sekitarnya (Bhairawa, Mulatsih, dan Rahayu, 2009; Pitana, 2002; Semercioz, Donmez, dan Dursun, 2008; Damanik, 2010). Akhirnya, diharapkan hasil penelitian ini dapat memberikan masukan langsung kepada organisasi pengelola destinasi, masyarakat, pemerintah, akademisi, dan elemen-elemen terkait.

\section{Konsep Tata Kelola Organisasi Destinasi}

Ada tiga konsep penting yang perlu disepakati maknanya berkenaan dengan kajian ini, yaitu (a) konsep manajemen, (b) konsep organisasi, dan (c) konsep destinasi. Pemaknaan konsep diperlukan untuk mencegah bias arti kata-kata tersebut. Kata management merupakan kata benda yang berasal dari bahasa Inggris dan telah diindonesiakan menjadi manajemen, artinya penggunaan sumber daya secara efektif dan efisien untuk mencapai sasaran. Sebagian masyarakat mengartikan bahwa manajemen sama dengan pengelolaan, yaitu proses sistemik perbuatan mengelola. Asumsi dasar dari pengelolaan organisasi destinasi pariwisata ini adalah sebuah sistem, yaitu satu kesatuan dari unsur-unsur yang saling berinteraksi untuk tujuan mengoptimalkan nilai-nilai penghidupan, kehidupan, kemanusiaan, keruangan yang berupa alam semesta, dan ketuhanan serta mendapatkan manfaat dari nilai tersebut secara adil (Baiquni, 2009). Nilai ini membentuk model bahwa keadilan manfaat dapat menentukan kuatnya dukungan terhadap organisasi pengelola destinasi pariwisata tersebut.

Kata organization merupakan kata benda yang berasal dari bahasa Inggris dan diserap ke dalam bahasa Indonesia menjadi kata kerja organisasi yang secara harfiah 
berarti mengatur. Secara khusus Gibson, Ivancevich, dan Donnelly (2011) menyatakan bahwa organisasi adalah suatu wadah yang mengatur dan memungkinkan kesatuan dari orang-orang atau kelompok orang dalam suatu perkumpulan berperilaku agar dapat meraih hasil optimal yang sebelumnya tidak dapat dicapai oleh individu. Pendekatan pengaturan organisasi dalam penelitian ini melalui perilaku keorganisasian. Perilaku keorganisasian didefinisikan sebagai studi tentang manusia bertindak dalam organisasi yang ditujukan bagi kemanfaatan orang (Tampubolon, 2004). Dari segi perilaku organisasi dapat dilihat dari dua sudut pandang, yaitu lingkungan eksternal dan lingkungan internal (Tampubolon, 2004:3).

Pengertian kata destinasi pariwisata dalam kaitannya dengan tata kelola organisasi dapat berupa tempat tujuan wisatawan, produk dan pelayanan yang menarik wisatawan, termasuk peradaban masyarakatnya, atau satu kesatuan pengalaman yang didapat oleh wisatawan yang dikelola oleh organisasi tersebut (Manente dan Minghetti, 2000). Hal ini juga ditegaskan dalam undangundang Nomer 10 Tahun 2009 tentang Kepariwisataan Pasal 1 Angka 6, yang menyatakan bahwa destinasi pariwisata adalah kawasan geografis yang berada dalam satu atau lebih wilayah administratif yang di dalamnya terdapat daya tarik wisata, fasilitas umum, fasilitas pariwisata, aksesibilitas, serta masyarakat yang saling terkait dan melengkapi terwujudnya kepariwisataan.

Jika ketiga kata tersebut dirangkaikan menjadi satu kesatuan makna MDO (Management of Destination-Organization), artinya adalah suatu sistem pengelolaan organisasi kepariwisataan terpadu yang mengintegrasikan fungsi perencanaan, pengorganisasian, pelaksanaan, dan pengawasan secara inovatif serta sistemik. Semua itu dijalankan melalui jaringan yang terpimpin secara terpadu dengan melibatkan peran masyarakat, asosiasi, industri, akademisi, dan pemerintah. Tujuannya ialah meningkatkan fungsi nilai sebagai tujuan akhir dan fungsi nilai yang dimaksud, sebagai berikut, (1) Berfungsi sebagai penggerak ekonomi lokal dalam menghasilkan pendapatan daerah, lapangan pekerjaan, dan penghasilan pajak. (2) Berfungsi sebagai pemasar lokal yang membentuk citra destinasi. (3) Berfungsi sebagai koordinator industri yang berkemampuan untuk meningkatkan pertumbuhan industri daerah dengan mendatangkan hasil dan keuntungan daerah melalui bisnis pariwisata. (4) Berfungsi sebagai lembaga yang mewakili pengelola destinasi pariwisata dalam berhubungan dengan pengunjung. (5) Berfungsi membangun dan menggali nilai kearifan lokal yang dapat memperkuat identitas kedaerahan dan menjadi kebanggaan.

Penelitian ini menggunakan pendekatan holistik dengan metode deskriptif-interpretatif. Pengumpulan data dilakukan dengan studi literatur, wawancara secara mendalam, observasi terlibat, dan penjaringan data melalui diskusi kelompok. Studi literatur dilakukan terkait dengan berbagai data, termasuk beragam pandangan dan analisis dari para ahli sebelumnya tentang potensi kepariwisataan dan organisasi pengelolanya di Desa Borobudur, baik berupa buku, jurnal, laporan penelitian, kliping media massa, proceding seminar, dan informasi dari internet. Wawancara secara mendalam dilakukan terhadap informan untuk mengetahui lebih jelas dan rinci dalam mengungkap bukti-bukti dan data dari informasi yang ada. Upaya penggalian data dan informasi pun juga dilakukan dengan pengamatan secara langsung terlibat dalam kegiatan masyarakat di sekitar kampung dan di situs Candi Borobudur. Fenomena yang terjadi diamati terkait perihal sosiokultural dan organisasi yang ada. Pengamatan ini dilakukan dengan cara mengamati, mencatat, dan menghubungkannya dengan beberapa data maupun informasi yang ada di lapangan. 
Diskusi kelompok dilakukan melalui beberapa acara temu sarasehan, workshop, dan presentasi seminar untuk membahas beragam pandangan. Forum-forum informal sebanyak lima kali didesain berupa diskusi dan perdebatan sebagai cara untuk menguji argumen, mengklarifikasi data dan informasi, dan menemukan pandangan baru dari proses berpikir kritis.

\section{PEMBAHASAN}

Berdasarkan pemahaman konsep manajemen organisasi destinasi di atas, data perilaku organisasi dari sudut pandang lingkungan internal dan eksternal diteliti untuk mengetahui pola tata kelola organisasinya.

\section{Tata Kelola Organisasi di Candi Borobudur}

Hasil analisis ini tersaji pada Bagan 1 dalam struktur organisasi PT. TWCPBB (Perseroan Terbatas. Taman Wisata Candi Prambanan, Borobudur, dan Boko) di bawah pengelolaan Kementerian BUMN (Badan Usaha Milik Negara) dan pengawasan Kementerian Pariwisata dan ekonomi kreatif. Tatanan lingkungan internal organisasi pada tiap-tiap candi dikepalai oleh seorang kepala unit dan dibantu seorang wakil kepala unit. Penelitian ini fokus pada TWC Borobudur. Tugas dan fungsi masing-masing jabatan dijalankan oleh satuan yang ada pada Subbagian Tata Usaha, Seksi Pelayanan Teknis, dan Kelompok Tenaga Fungsional dalam suatu sistem yang cukup baik.

Mereka semua bekerja dengan mengemban satu visi PT Taman Wisata Candi Borobudur.

Menjadikan perusahaan yang mempunyai kemampuan dan kompetensi yang tinggi serta profesional dengan dukungan sumber daya manusia yang berkualitas untuk menjadikan taman dan candi sebagai objek dan daya tarik wisata yang mampu bersaing secara global (Kurniawati, 2008).

Berdasarkan visi ini, TWC Borobudur mengalami kemajuan pesat. Mereka

Bagan 1

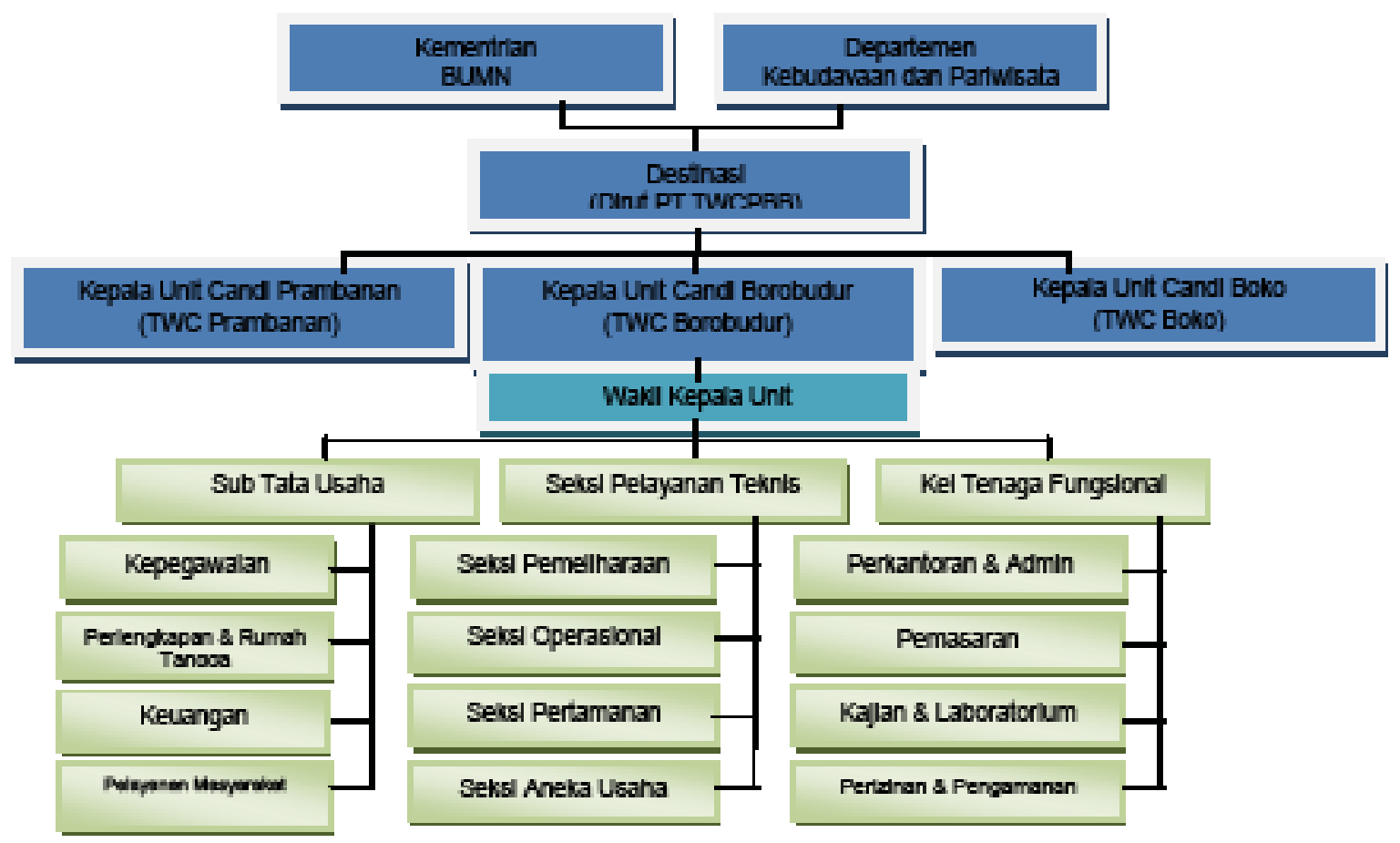

Sumber : Data Lapangan Candi Borobudur 
melakukan pembenahan dan penataan terhadap lingkungan candi melalui pembangunan Taman Wisata Candi Borobudur ini. Pada 23 Februari 1983 pemugaran Candi Borobudur diresmikan oleh Presiden Soeharto. Selanjutnya, pada 13 Desember 1991 Candi Borobudur terdaftar sebagai The World Cultural Heritage dengan nomor registrasi C.592 (Ibrahim dan Chaeosti, 1997:2526). Berbagai piagam dan penghargaan diraihnya, bahkan terakhir memenangkan kompetisi internasional Gold Awards sebagai pengelola heritage terbaik dari PATA (Pacific Asia Trade Association) di Beijing, Cina pada 11 April 2011.

Fenomena lingkungan internal tanpa melihat lingkungan eksternalnya menjadi sesuatu yang paradoksal bila dijadikan referensi untuk menilai perkembangan destinasi Borobudur yang hingga sekarang masyarakat di sekitarnya masih miskin. Penguatan visi ini hanya akan memperkuat kesenjangan antara kemegahan Candi Borobudur dan kemiskinan masyarakatnya. Dukungan masyarakat yang semula diharuskan mengorbankan tanahnya untuk kepentingan yang lebih besar dengan ganti rugi yang tidak seberapa (Kompas, 6 Februari 1981) tidak dimaknai dengan baik dalam visi tersebut. Williams dan Lawson's (2001) mengatakan hal tersebut sebagai berikut.

...If it is known why residents support or oppose the industry, it will be possible to select those developments which can minimise negative social impacts and maximise support for such alternatives. As such, quality of life for residents can be enhanced, or at least maintained, with respect to the impacts of tourism in the community.

Visi organisasi yang ideal bukan hanya mengobsisi pikiran dan tindakan internal organisasi, tetapi juga eksternalnya, yaitu segenap pihak terkait (Kaho, 2002; Nasikun, 2003). Visi TWC Borobudur sebagai perusahaan BUMN tidak terintegrasi dengan visi Kementerian BUMN, yaitu meningkatkan peran BUMN sebagai instrumen negara untuk peningkatan kesejahteraan rakyat berdasarkan mekanisme korporasi. Visi TWC Borobudur juga tidak mendukung rumusan visi pariwisata Indonesia, yaitu menumbuhbinakembangkan kesejahteraan (Agenda 21 Sektoral, 2000). Hal ini agaknya mengisyaratkan bahwa penentuan visi seharusnya mampu menyejahterakan masyarakat, yang barangkali dapat dikaitkan dengan arti penting pariwisata dan dukungan masyarakat ketika mengorbankan tanahnya. Pariwisata dimaksudkan bukan sebagai tujuan, tetapi merupakan salah satu jalan menuju kesejahteraan masyarakatnya (Suharto, 2011). Seiring dengan pendapat tersebut, amanah Undang-Undang Nomer 10 Tahun 2009 tentang Kepariwisataan menegaskan bahwa peninggalan purbakala, peninggalan sejarah, seni, dan budaya yang dimiliki bangsa Indonesia merupakan sumber daya dan modal pembangunan kepariwisataan untuk peningkatan kemakmuran dan kesejahteraan rakyat. Ada pengulangan yang juga memperkuat pendapat tersebut, yaitu Crouch dan Ritchie (1999) menyatakan sebagai berikut.

...not only will tourism be a major contributor to global prosperity, but also ... the very nature of the tourism phenomenon will shape the lifestyles, societal structures, and inevitably the quality of life...of many citizens of the world during the first segment of the third millennium.

Sehubungan dengan itu, pembangunan kepariwisataan berkontribusi terhadap kemakmuran sosial (societal prosperity) serta mampu menghadapi tantangan perubahan kehidupan lokal, nasional, dan global. Negara mempunyai kewajiban menjalankan dan mengawasi hal tersebut. Hartanto (1997:49) menyatakan bahwa semakin optimal kontribusi tersebut, semakin banyak lingkup jumlah manusia, luas, dan lama intensitas terkena kontribusi tersebut. 
Berdasarkan hipotesis studi ini, terlihat bahwa dibandingkan dengan masyarakat yang ada di desa-desa yang lain di Kabupaten Magelang, yang letaknya lebih jauh dari candi Borobudur tempat pengembangan pariwisata ini, seharusnya masyarakat di sekitar Candi Borobudur makmur dan sejahtera terlebih dahulu. Namun, hasil penelitian ini menunjukkan realitas lain.

Realitas itu dapat dijelaskan melalui faktor kepemimpinan. Peran pemimpin TWC Borobudur merupakan salah satu kunci sukses untuk menggerakkan segenap potensi dengan syarat mutlak mengetahui karakter pranata sosial, budaya, dan adat setempat. Misalnya, Dirut TWC Borobudur direkrut dari masyarakat lokal yang mempunyai kualifikasi di bidang tersebut dan memahami adat setempat (Best practice dari Bali Tourism Development Corporation dan Sekolah Tinggi Pariwisata Bali). Apabila masyarakat tidak pernah diberikan kepercayaan dan tanggung jawab memimpin, selamanya mereka tidak akan pernah bisa. Pemimpin tidak hanya membutuhkan keahlian manajerial dan teknis saja, namun keahlian non teknis, seperti pemahaman karakteristik pranata sosial masyarakat di sekitar Candi Borobudur penting. Sentuhan-sentuhan bersifat kedaerahan dalam suasana kekeluargaan dan dialog kerap kali terbukti mampu menyelesaikan kebekuan organisasi dan distorsi kepentingan tersebut (Satrya, 2011).

Seiring dengan berjalannya waktu, perekrutan, dan pergantian generasi sumber daya manusia sejak 1973 masih kurang mengoptimalkan masyarakat sekitarnya dengan alasan tidak tersedianya kesesuaian pendidikan dan keahliannya (Kepegawaian TWC Borobudur, 2011). Namun, hal ini terjadi bertahun-tahun tanpa ada kaderisasi dan regenerasi dari masyarakat sekitar sebagai karyawan atau pimpinan sesuai dengan kualifikasinya. Warga masyarakat di dua puluh dusun sekitar Borobudur, tercatat 95\% masih membutuhkan pekerjaan (Kurniawati,
2008). Sementara itu, kegiatan program diklat, bintek, pemagangan diprogramkan secara berkelanjutan dengan anggaran yang cukup besar oleh TWC Borobudur untuk karyawannya yang bukan berasal dari masyarakat sekitar Borobudur (BKPCB, 2011). Kroc dalam Hunger dan David (1995) menyatakan bahwa keberanian mengambil keuntungan dari suatu daerah, harus ada imbal baliknya agar keuntungan tersebut berkelanjutan. Selanjutnya dikatakan bahwa ketidakmampuan masyarakat sekitarnya dipekerjakan oleh suatu perusahaan merupakan konsukuensi tanggung jawab sosial perusahaan mendidiknya. Hal itu konsekuensi perusahaan mengambil keuntungan di daerah tersebut, kecuali mereka tidak menginginkannya karena masyarakat daerah tersebut sudah makmur. Data hasil wawancara mendalam dengan informan sebagai berikut.

Saya dibantu istri bekerja mencari batu di sungai untuk makan setiap hari. Anak dititipkan ke pondok pesantren biar jadi orang baik, karena tidak punya biaya banyak untuk sekolah. Ingin sebenarnya bekerja dekat-dekat di kawasan candi Borobudur biar bisa kumpul keluarga, namun tidak sekolah, tidak punya kenalan, dan tidak punya uang untuk modal kan tidak bisa.

(wawancara mendalam dengan informan)

Hal lain yang harus dicermati oleh pemimpin TWC Borobudur adalah program CSR (Corporate Social Responsibilities). Program CSR ini baru berupa jasa melayani dan mendampingi tamu-tamu dinas, tamu kantor, hari besar waisak, dan kegiatan pemanfaatan Candi Borobudur untuk acara festival (Seksi Pelayanan Masyarakat TWC Borobudur, 2011). Kegiatan sosialisasi dan penyuluhan kepada masyarakat hanya berupa pemberian informasi dalam mengemban kepentingan organisasi pengelola Candi Borobudur. Berbagai acara baik murni ritual maupun ritual yang sekedar untuk menyemarakkan pariwisata dilakukan oleh masyarakat di 
sekitar Candi Borobudur, seperti Ruwatan Borobudur, Sedekah Kedung Winong, Sedekah Gunung, Sedekah Kali Sibendha, Pasar Ngumandang Mirunggan, Jamasan Keris, Tetesan, Ritual Gaib, Renungan Dharma Budaya Siwi, Sedekah Tuk Pitu, Sedekah Punthuk Setumbu, dan masih banyak lagi tanpa bantuan TWC Borobudur. Padahal ritual ini juga suatu atraksi yang berpotensi yang mempunyai relevansi dengan keberadaan Candi Borobudur (Sucoro, 2011). TWC Borobudur belum memandang potensi masyarakat dan tanggung jawab sosial sebagai sesuatu yang semakin aktual dan relevan ketika dikaitkan dengan sasaran strategis bisnis yang mengemban asas keadilan sosial sebagaimana diamanatkan juga dalam Undang-Undang Nomer 40 Tahun 2007 Bab V Pasal 74 tentang Tanggung Jawab Sosial Perseroan Terbatas.

Program CSR TWC Borobudur seharusnya didefinisikan bersama warga yang dikenai tanggung jawab sosial tersebut, seperti halnya konsep 3P, yaitu potensi, peluang, dan proteksi (Suharto, 2011). TWC Borobudur melakukan pengembangan kapasitas potensi masyarakat. Masyarakat yang sudah berpotensi harus diberi akses untuk mengaktualisasikan kebolehannya. Mereka ini penting untuk dilindungi agar yang baru saja mempunyai potensi tidak tersaingi oleh pesaing di pasar bebas yang lebih kuat serta berpengalaman.

Perilaku lain yang direkomendasikan kepada organisasi TWC Borobudur ini, khususnya bagiankeuanganadalahmelakukan program kajian dengan merangsang, membina, dan memberikan pinjaman modal, sarana dan prasarana, informasi usaha, kemitraan, perizinan usaha, kesempatan berusaha, pendampingan, promosi dagang, serta dukungan kelembagaan kepada masyarakat pengusaha mikro di sekitar Candi Borobudur. Program kemitraan dengan usaha kecil dan program bina lingkungan didasarkan pada Peraturan Menteri Negara
BUMN Nomor PER-05/MBU/2007 dan Undang-Undang UMKM (Usaha Mikro Kecil dan Menengah) Nomer 20 Tahun 2008 pasal 7 tentang usaha mikro, kecil, dan menengah. Dana program kemitraan ini, disisihkan dari laba BUMN setelah dikurangi pajak maksimal $1 \%-5 \%$ (rata-rata $2 \%$ ) atau hasil bunga pinjaman, bunga deposito, dan jasa giro dari dana kemitraan setelah dikurangi beban operasional. Usaha mikro diarahkan untuk menumbuhkembangkan usaha kreatif rumahan atau industri jasa pariwisata di bawah pengelolaan LWG (Lokal Working Group) di 20 dusun yang ada di Desa Borobudur tersebut, seperti konsep amoeba (Pearce, 1989; Mclalland, 2008). Program ini didorong untuk menginspirasi kesadaran pola pikir masyarakat bahwa mereka tidak hanya menjadi pedagang di Borobudur saja, tetapi justru menjadi pengusaha jasa kepariwisataan lain di rumahnya atau di desanya sendiri yang jauh lebih menguntungkan. Usaha-usaha kreatif inilah yang harus mendominasi aktivitas dan kegiatan kepariwisataan di Bhumisambhara ini. Mereka yang mempunyai usaha-usaha kreatif ini juga menjadi pengelola destinasi di usahanya masing-masing.

Mereka yang mempunyai usaha kreatif jasa kepariwisataan sejenis di tingkat lokal ini dapat membentuk asosiasi sebagai wadah untuk mencari penyelesaian ke arah pengembangan usahanya. Misalnya, ketua organisasi-organisasi yang terdiri dari perwakilan pengusaha pariwisata, asosiasi usaha pariwisata, asosiasi profesi, LWG sejenis, dan asosiasi lain yang terkait tersebut membentuk asosiasi yang lebih besar lagi, yaitu GIPD (Gabungan Industri Pariwisata Daerah) di tingkat provinsi dan GIPI (Gabungan Industri Pariwisata Indonesia) di tingkat pusat. GIPD dan GIPI dipilih oleh anggotanya yang mencerminkan prinsip-prinsip partisipatif, transparan, demokratis, akuntabilitas, berorientasi hasil, dan berkelanjutan melalui tahapan 
perintisan.

Organisasi yang sudah dirintis tersebut perlu diberi dukungan, legalisasi, dan akses operasional. Fungsi kedua asosiasi ini penting sebagai mitra kerja TWC Borobudur, Pemerintah daerah, dan Pemerintah Pusat yang independen. GIPD dan GIPI berfungsi sebagai wadah komunikasi, menyalurkan aspirasi, memelihara kerukunan, konsultasi para anggota, mengemban kepentingan, dan pengawasan bersama dalam rangka keikutsertaannya dalam penyelenggaraan pembangunan kepariwisataan. Keberadaan GIPD dan GIPI juga dapat mengurangi kecenderungan kepemimpinan yang otoriter. Asosiasi ini juga dapat mengurangi pihakpihak yang cenderung tidak transparan yang memungkinkan praktik kolusi dan nepotisme sebagai sumber permasalahan ketidakadilan. Kedua organisasi itu bersifat mandiri dan dalam melakukan kegiatannya bersifat nirlaba. Ketentuan lebih lanjut mengenai bentuk, keanggotaan, susunan kepengurusan, dan kegiatannya diatur dalam anggaran dasar dan anggaran rumah tangga (UU No 10 Th 2009).

\section{Tata Kelola Organisasi Destinasi Terintegrasi}

Keterkaitan TWC Borobudur dan asosiasi pengusaha menjadi satu kesatuan MDO yang terintegrasi bersama asosiasi profesi, akademisi, dan pemerintah, seperti pada bagan 2 .

Walaupun struktur organisasi MDO terbentuk, permasalahan tetap saja tak kunjung tuntas diatasi ketika dihadapkan pada persoalan kontribusi pengelola destinasi candi di tengah-tengah tradisi dan praktik kehidupan masyarakat yang diidealkan adil dan sejahtera. Sering terjadi dalam suatu organisasi bahwa bila berkait dengan hal kewenangan selalu berebut dan bila dihadapkan pada tanggung jawab atau masalah saling melimpahkan atau cuci tangan. Dalam kaitan ini, agaknya mengisyaratkan bahwa karakter TWC Borobudur sebagai aktor bisnis dituntut mampu memberikan contoh kepada swasta dalam merespons hal tersebut.

Setiap proses pemilihan pemimpin yang akan duduk pada struktur organisasi yang ada pada MDO seharusnya mencerminkan prinsip-prinsip partisipatif, transparan, demokratis, akuntabilitas, berorientasi hasil, dan berkelanjutan. Koordinator asosiasi lokal dalam panduan DMO Budpar 2010 ini adalah seseorang yang ditunjuk oleh Proyek Manager. Penunjukan langsung ini membuat pimpinan koordinator ini cenderung bekerja mengabdi kepadanya, bukan kepada anggota. Pemilihan dengan penunjukan langsung tersebut sulit untuk mendapatkan dukungan, akses operasional, dan sulit untuk menjalin sinkronisasi program pengembangan kemitraan. Cara-cara ini hanya akan memperkuat kekuasaan yang terjalin antara destinasi TWC Borobudur, Pemerintahan Kabupaten, Pemerintahan Provinsi, dan Pemerintahan Pusat. Pada bagan struktur organisasi DMO Budpar, antara destinasi TWC Borobudur atau destinasi (n) dengan masyarakat lokal atau kelompok-kelompok subunit LWG atau organisasi lokal hanya mengenal garis pengendalian. Para pemangku kepentingan dari kelompok-kelompok subunit asosiasi lokal berada pada sistem yang tidak mempunyai kekuatan, mereka tersandera oleh ketergantungan kebijakan like/dislike destinasi TWC Borobudur. Usahausaha untuk menjalin kerja sama yang tidak henti-hentinya dilakukan kelompok asosiasi lokal melalui pertemuan-pertemuan formal dan nonformal bukan hal yang bersifat wajib bagi TWC Borobudur. Namun demikian, kebutuhan sinergitas ini penting (Utami, 1998). Data hasil wawancara mendalam dengan informan sebagai berikut.

Saya sering mengundang Bapak Dirut TWC maupun Bapak Kepala Unit TWC Borobudur untuk menghadiri acara ritual masyarakat seperti sedekah Punthuk Setumbu, Mirunggan, 
Bagan 2

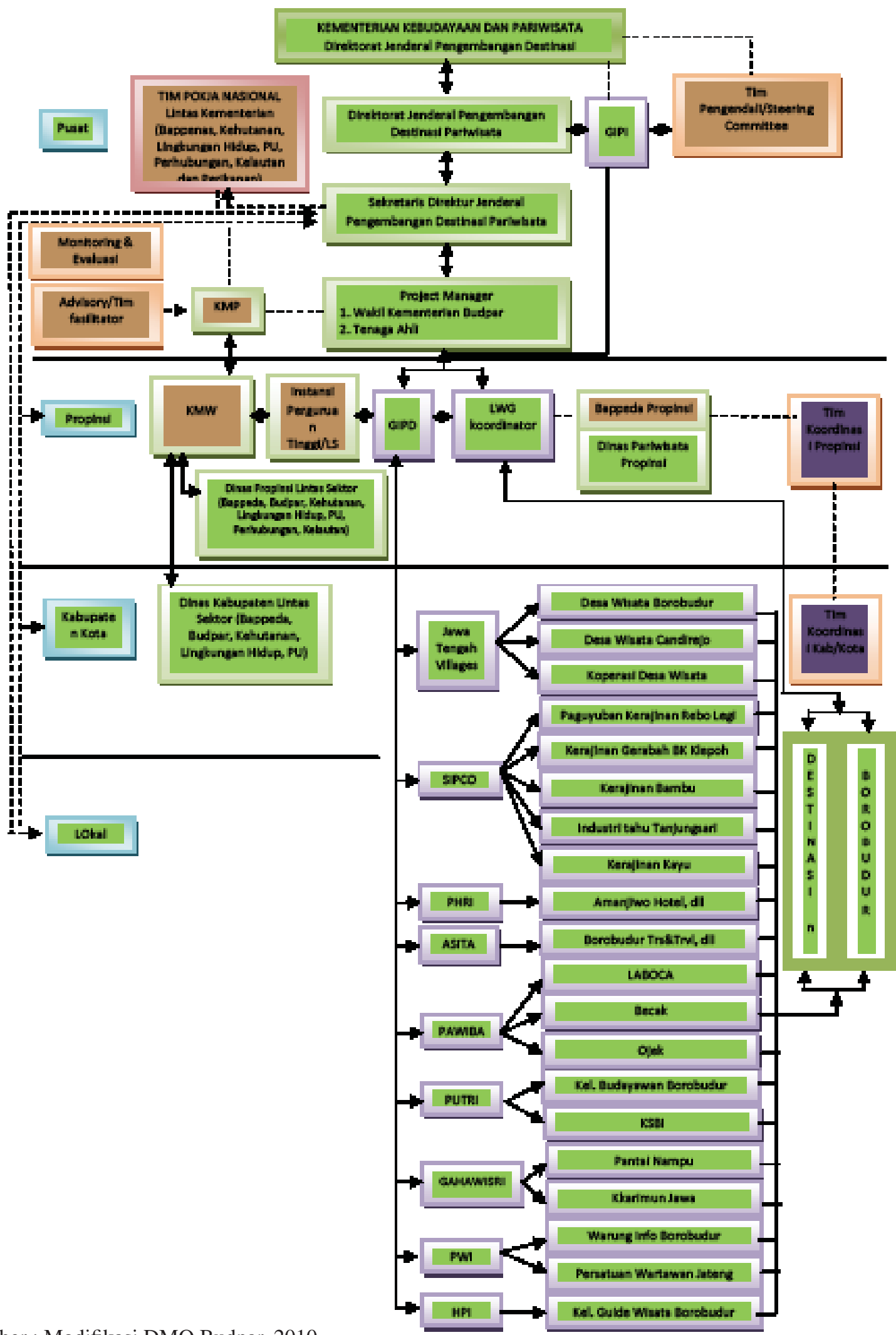

Sumber : Modifikasi DMO Budpar, 2010 
Workshop dengan tema CSR, Sarasehan rembuk desa, dan lokakarya pengelolaan candi Borobudur, namun tidak pernah hadir. Pernah sekali seminar DMO dari Budpar, namun, masyarakat tidak mengerti apa itu DMO. Sebagian dari meraka datang ingin menyuarakan keluhan yang hingga kini belum tuntas dan sebagian lagi yang penting datang, makan-makan, dan dapat uang saku. (Wawancara mendalam dengan informan)

Hal ini mengisyaratkan bahwa proses koordinasi dan sosialisasi tidak berjalan baik. Berdasarkan pola ini, telah terjadi kesenjangan pada Bagan 2, terutama pada tataran lokal, yaitu antara Local Working Group (LWG) dengan petugas fungsional, struktural, dan pelaksana pengelola destinasi. Petugas fungsional melibatkan tim Pokja (Kelompok Kerja), KMP (Konsultan Manajemen Pusat), dan KMW (Konsultan Manajemen Wilayah. Petugas struktural meliputi Kementerian Pariwisata dan Ekonomi Kreatif, Dirjen Pengembangan Destinasi Pariwisata, Sekditjen Pengembangan Destinasi Pariwisata, Projek Manager, dan Koordinasi asosiasi lokal. Petugas pelaksana pengelola destinasi adalah TWC Borobudur. Petugas fungsional, struktural, dan pengelola destinasi tampaknya kurang mampu berinteraksi dengan masyarakat, yang barangkali dapat dikaitkan dengan arti penting integritas organisasi yang selama ini masih lemah, semrawut, dan tidak berjalan di tingkat lokal atau LWG sebagaimana pada tataran konseptual.

Mengacu pada tupoksi panduan (DMO, 2010), integritas pengelola organisasi ini dapat diidentifikasi dari karakter dasar yang melekat pada setiap aktor. Ketidaksesuaian ditunjukkan ketika melihat temuan tugas pokok dan fungsi panduan DMO Budpar dengan munculnya permasalahan yang mengisyaratkan hal-hal berikut. Tim pengarah kurang mengawasi dan kurang mengevaluasinya dengan melakukan tindak turun tangan yang diperlukan. Konsultan manajemen pusat yang ditugaskan kurang melakukan analisis, koordinasi, dan kurang memberikan masukan kepada Pemerintah Pusat berupa visi yang mengembangkan kepariwisataan untuk kemakmuran dan kesejahteraan masyarakat sekitarnya. Unit Manajemen Proyek DMO dianggap kurang melakukan koordinasi, pengawasan, dan kurang melakukan kajian evaluasi untuk sinkronisasi pada asosiasi yang ada di daerah. Begitu juga, Konsultan manajemen wilayah kurang melakukan analisis, koordinasi, dan konsultasi kepada Pemerintah Daerah berupa masukan untuk mengembangkan kemitraan LWG. Padahal, LWG berfungsi sebagai wadah koordinasi penyelesaian masalah dan mitra kerja jajaran Departemen Kebudayaan dan Pariwisata di tingkat operasional yang paling bawah dan terpenting.

Dapat diamati dari Bagan nomor 2 dalam kaitannya dengan persepsi masyarakat bahwa cenderung ada pergeseran iritasi indeks dari masyarakat yang sebelumnya bersikap euphoria berubah menjadi apathy, kemudian annoyance, dan sekarang antagonism (Doxey, 1975 dalam Monterrubio-Cordero, 2008). Persepsi antagonism ini diperkuat oleh tipe pengelolaan wisata dengan sistem tertutup yang berdampak pada interaksi sosial yang cenderung rendah (PAU-UGM, 1991). Hal ini terlihat pada kompleks zona candi yang didesain sedemikian rupa sehingga memiliki posisi eksklusif yang berjarak dengan kehidupan masyarakat di sekelilingnya (Gunn, 1994). Kemudian, desain dan pembiaran ini membangun persepsi masyarakat tentang pengelolaan organisasi destinasi di Borobudur yang bersifat sentralistis. Panjangnya aturan birokrasi dan egoisme dari kepentingan politis dalam pengelolaan hanya berada di seputar pejabat pemerintah pusat, pemerintah daerah, dan pengusaha destinasi (Peer Discussion, 2011).

Dugaan kepentingan yang menguntungkannya sebagai alibi politis adalah mereka bekerja secara normatif pada sistem kebijakan yang sudah ada, seperti Keputusan Presiden Nomer 1 Tahun 1992, Peraturan Daerah Kabupaten Magelang 
Nomer 17 Tahun 2002, dan Surat Keputusan Direksi Perseroan Terbatas Taman Wisata Candi Borobudur Nomer 4 Tahun 2003 (Tupoksi, 2011). Keputusan Presiden Nomer 1 Tahun 1992 mengatur tentang kewenangan Taman Wisata Candi Borobudur dalam pengelolaannya di zona II. Peraturan Daerah Kabupaten Magelang Nomer 17 Tahun 2002 mengatur tentang tata tertib secara umum. Adapun tata tertib secara khusus sebagai tindak lanjut dari Peraturan Daerah tentang pengelolaan, keamanan, dan ketertiban di lokasi objek wisata diatur oleh Surat Keputusan Direksi TWC Borobudur. Artinya, segala bentuk kebijakan perencanaan, pengembangan, dan pengelolaan kawasan sudah menjadi kewenangannya.

Hasil analisis dan temuan penelitian ini menunjukkan bahwa pemimpin pemegang kewenangan tersebut gagal dalam menjalankan tanggung jawab sosialnya. Pemimpin TWC Borobudur lalai dalam menjalankan visi BUMN, UU No. 40 Tahun 2007, dan UU No. 10 Tahun 2009. Dari segi perilaku keorganisasian, TWC Borobudur kurang berkomitmen menjalankan tupoksi panduan DMO 2010, CSR, dan misi BUMN mengenai UMKM. Analisis ini mengisyaratkan pentingnya perubahan kebijakan perekrutan (Satrya, 2011; Hunger dan David, 1995), perubahan visi (Visi BUMN, 2011; UU No. 40 Tahun 2007; UU No. 10 Tahun 2009), ketepatan program CSR yang dilakukan oleh organisasi (Suharto, 2011) dan penguatan bantuan modal lunak kepada usahausaha kreatif UMKM (Usaha Mikro, Kecil, dan Menengah) dalam memberdayakan masyarakat di lingkungan Candi Borobudur (Damanhuri, 2011), dan diperlukan aplikasi modifikasi struktur organisasi DMO, seperti terkait pada Bagan 2. Sehubungan dengan hal itu, tata kelola organisasi daerah tujuan wisata yang baik akan menghasilkan pengelolaan destinasi yang baik. Hal itu akan membawa manfaat pada kesejahteraan masyarakat sekitarnya (Greech, 1995:517; Bhairawa, Mulatsih, dan Rahayu, 2009; Pitana, 2002; Semercioz, Donmez, dan
Dursun, 2008; Damanik, 2010).

\section{SIMPULAN}

Dari pembahasan di atas dapat disimpulkan bahwa pengembangan organisasi Candi Borobudur yang baik, juga akan memunculkan perilaku keorganisasian yang baik. Perilaku keorganisasian yang baik akan mempunyai komitmen yang baik terhadap tanggung jawab hukum, tanggung jawab ekonomi, dan tanggung jawab sosialnya. Komitmen organisasi yang baik ini akan menjalankan proses pengelolaan destinasi dengan baik. Organisasi yang menjalankan pengelolaan destinasi yang baik akan menghasilkan kesuksesan destinasi yang baik. Kesuksesan destinasi yang baik ialah apabila mampu memberikan manfaat seoptimal mungkin secara adil dan merata. Keadilan dan pemerataan manfaat destinasi ini akan mendukung keberlanjutan pengembangan organisasi yang baik. Sistem yang sudah terbangun tersebut dapat diterapkan dengan model struktur organisasi MDO yang sudah dimodifikasi pada Bagan 2. MDO hasil modifikasi tersebut merupakan rujukan alternatif bagi para pengelola destinasi pariwisata daerah agar selalu menjadi lebih baik.

\section{DAFTAR PUSTAKA}

Baiquni, M, 2009, Belajar dari Pasang Surut Peradaban Borobudur dan Konsep Pengembangan Pariwisata Borobudur, Forum Geografi, Jurnal Geografi Universitas Muhammadiyah Surakarta. Vol. 23, No. 1, Juli, hlm.25-40.

Bhairawa, P., Mulatsih, S., dan Rahayu, S, 2009, "Destination Management Organization (DMO): Paradigma Baru Pengelolaan Pariwisata Daerah Berbasis Teknologi Informasi", Seminar Nasional Aplikasi Teknologi Informasi (SNATI), Yogyakarta, 20 Juni.

Buhalis, D, 2000, The Competitive Destination 
of the Future, Tourism Management, 21 (1), hlm. 97-116.

Chen, H, dan Sheldon, P.J, 1997, Destination Information System: Design Issue and Directions, Journal of Management Information Systems, Vol. 14, No. 2, hlm. 151-17.

Crouch, G. dan J.R.B. Ritchie, 1999, Tourism, Competitiveness, and Societal Prosperity, Journal of Business Researc. 33(3), hlm. $137-152$.

Damanhuri, D., S, 2011, “Kemitraan Usaha Skala Besar (USB) dengan Usaha Kecil dan Menengah (UKM) dalam Perspektif Pemberdayaan Masyarakat", Bunga Rampai Pemberdayaa Masyarakat Jawa Barat, hlm. 145-156, Belum diterbitkan.

Damanik, J, 2010, “Merancang Format Baru Pariwisata yang Menyejahterakan Rakyat", Pidato Pengukuhan Jabatan Guru Besar pada Fakultas Ilmu Sosial dan Ilmu Politik UGM.

Budpar, 2010, "Pedoman Pembentukan dan Pengembangan Destination Management Organization (DMO)", Dirjen Pengembangan Destinasi Pariwisata, Kementerian Kebudayaan dan Pariwisata.

Fodor, O. dan Werthner, H, 2005, Harmonise: A Step Toward an Interoperable E-Tourism Marketplace, International Journal of Electronic Commerce, Vol. 9, No. 2, pp, hlm. 11-39.

Getz, D., Anderson, D., dan Sheehan, L, 1998, Roles, Issues, and Strategies for Convention and Visitors Bureaux in Destination Planning and Product Development: A Survey of Canadian Bureaux, Tourism Management, 19 (4), hlm. $331-340$.

Gibson, J.L., Ivancevich, J.M., dan Donnelly,
J.H, 2011, Organisasi: Perilaku, Struktur, dan Proses, Edisi ke-8, Jakarta: Binarupa Aksara.

Greech, B, 1995, The Five Pillars of Total Quality Management, Jakarta: Binarupa Aksara.

Gunn, C., A. 1994, Tourism Planning, Basics Concepts Cases, Washington: Taylor \& Francis.

Hartanto, F., M, 1997, Towards Sustainable Tourism Development: A Policy Planning Perspective, Bandung: ITB.

Hunger, W, dan David, J, 1995, Strategic Management, USA: Addison-Wesley.

Ibrahim, M., dan Chaerosti, L, 1997, Borobudur dalam Data, Jakarta: Direktorat Jenderal Kebudayaan, Departemen Pendidikan dan Kebudayaan.

Kurniawati, R. 2008, “Geger Bhumisambhara: Ketegangan Relasi dan Sinergi antara Rakyat, Perusahaan, dan Negara dalam Pengelolaan Kawasan Pariwisata Borobudur", Skripsi.

Manente, M. dan Minghetti, V, 2000, Destination Management Organizations and Actors, http://www.download-it, Org/ learning-resources.

McElroy, J.L, 2003, Tourism Development in Small Islands Across the World, Geografiska Annaler, Series B, Human Geography, Vol. 85, No. 4, Special Issue: Nature-Society Interactions on Islands, hlm. 231-242.

Monterrubio-Cordero, J.C. 2008, Recidents' Perception of Tourism: A Critical Theoretical and Methodological Review, Ciencia Ergo Sum, Marzo-Junio, Ano/ Vol.15, Numero 001, pp. 35-44.

PAU-UGM, 1991, Penyusunan Indikator Sosial Ekonomi dan Sosial Budaya di Bidang Pariwisata.

Pearce, A, 1989, Tourism A Community Approach 
$2^{\text {nd }} E d$, USA: Longman Harlow.

Pitana, I., G, 2002, Apresiasi Kritis terhadap Kepariwisataan Bali, Bali: PT The Works.

Presenza, A., Sheehan, L., dan Ritchie, J., R., B, 2005, Towards a Models of The Role and Activities of Destination Management Organization, Destination Stakeholders: Exploring Identity and Salience, Annals of Tourism Research. 32 (3), $711-734$.

Ritchie, J., R. dan Crouch, G., I, 2007, A National Framework For Best Practice Destination Management Planning, The Competitive Destination - A Sustainable Tourism Perspective, Wallingford, UK: CAB International, Oxfordshire Publishing.

Satrya, D., G, 2011, Perilaku Keorganisasian Surabaya Tourism Promotion Board, Jurnal Manajemen Usahawan Indonesia, Vo. 40, No. 4, Juli.

Semercioz, F., Donmez, D., dan Dursun,M, 2008, Relationships Between Destination Management Organizations and Destination Stakeholders A Research in
Regions of Marmara in Turkey, Journal of Commerce \& Tourism Education Faculty, No.1, hlm. 87-1001.

Suharto, B, 2011, Kontribusi Hotel terhadap Kesejahteraan Masyarakat Lokal, Jurnal Kepariwisataan Indonesia, Jurnal Penelitian dan Pengembangan Kepariwisataan. Vol.6, No.1, hlm. 2742.

Tampubolon, M., P, 2004, Perilaku Keorganisasian, Jakarta: Ghalia.

Utami, S., D. 1998, “Pelaksanaan Koordinasi antar- Pelaku Pariwisata dalam Pengembangan Obyek Wisata di Daerah Istimewa Yogyakarta", Tugas Akhir.

UU No. 10 Tahun 2009, Tentang Kepariwisataan.

UU No. 40 Tahun 2007, Tentang Tanggung Jawab Sosial Perseroan Terbatas.

Williams, J dan R. Lawson, 2001, Community Issues and Resident Opinions of Tourism, Annuals of Tourism Research, 28(2): $269-290$. 